\title{
Salinomycin Concentration in Eggs and Tissues of Laying Hens
}

\author{
K. ŠINIGOJ-GAČNIK ${ }^{1}$, O. ZORMAN ROJS ${ }^{2}$ \\ ${ }^{1}$ Institute for Food Hygiene and Bromatology \\ ${ }^{2}$ Institute for Health Care of Poultry \\ Veterinary Faculty, University of Ljubljana, Slovenia
}

Received August 24, 2006

Accepted April 14, 2008

\begin{abstract}
Šinigoj-Gačnik K., Zorman Rojs O: Salinomycin Concentration in Eggs and Tissues of Laying Hens. Acta Vet. Brno 2008, 77: 423-429.

The objective of our study was to monitor the presence of salinomycin in eggs and tissues of laying hens fed with rations containing $60 \mathrm{mg} \cdot \mathrm{kg}^{-1}$ salinomycin sodium for five days. Residues of salinomycin were determined on the day of withdrawal from salinomycin treatment in the breast and thigh muscle, liver, abdominal fat and ovarian yolk. In eggs, residues of salinomycin were monitored in both yolk and albumen daily from the beginning of treatment until the tenth day after withdrawal. Salinomycin was first found in yolk 1 day after starting the treatment and persisted for 8 days after withdrawal. The highest average level, $480 \mu \mathrm{g} \cdot \mathrm{kg}^{-1}$, was present on the third day after withdrawal. In albumen, levels of salinomycin residues were significantly lower, with a maximum level of $15 \mu \mathrm{g} \cdot \mathrm{kg}^{-1}$ reached on the fifth day of the experiment; and they were only found up to one day after withdrawal. Salinomycin was found in all ovarian yolks present in the body of layer hens in a concentration range between 237 and $553 \mu \mathrm{g} \cdot \mathrm{kg}^{-1}$. It was also found in the abdominal fat (concentration range from 62 to $237 \mu \mathrm{g}^{\mathrm{kg}} \mathrm{kg}^{-1}$ ) and the liver (concentration $\leq 10 \mu \mathrm{g} \cdot \mathrm{kg}^{-1}$ ), but not in breast or thigh muscle tissues. No changes in salinomycin residues were observed after cooking and frying the eggs.
\end{abstract}

Salinomycin, poultry tissues, eggs, residues, cooking, residue stability

Salinomycin (SAL) is a monovalent polyether antibiotic with ionophoric properties which is used worldwide as a feed additive for the prevention of coccidiosis in poultry broilers, turkeys and replacement chickens. Several reports have been made on the toxic effects of SAL during the past decades. Toxic syndromes may result from its misuse which has occurred when SAL was administered to species for which it was not intended such as horses (Rollinson et al. 1987; Nicpon et al. 1997) and turkeys (Stuart 1983; Franz et al. 1992; Andreasen and Schleifer 1995; Van Assen 2006) or from adverse interactions with a simultaneously administered drug (Miller et al. 1986; Wendt et al. 1997). Salinomycin is not intended for layer hens. Nonetheless, residues of SAL in poultry products for human consumption, especially eggs, may occur if laying hens receive a feed contaminated with broiler feed that contains SAL. As reported by Hoop (1998), increased mortality, cannibalism, reduced food intake, decreased egg production and a significant reduction in hatchability was observed when a feed containing $77 \mathrm{mg} \cdot \mathrm{kg}^{-1} \mathrm{SAL}$ was accidentally administered to layer breeders. The occurrence of a significant drop in hatchability caused by SAL was reported by Jones et al. (1990) because of the foetotoxic effect of SAL (Atef et al. 1989). Kan et al. (1990) reported the carry-over of low levels of coccidiostats from layer feed to eggs, and Kennedy et al. (1996) presented the results of monitoring the presence of ionophore antibiotics in eggs from Northern Ireland. Akhtar et al. (1996) studied the concentration of SAL in eggs after feeding the birds with a feed containing between 30 and $150 \mathrm{mg} \cdot \mathrm{kg}^{-1} \mathrm{SAL}$; they reported that in yolk the concentration of SAL three days after withdrawal ranged between 57 and $300 \mu \mathrm{g} \cdot \mathrm{kg}^{-1}$ and depended on the concentration of SAL in the feed. Similarly high concentrations of SAL in yolk were reported by Hoop (1998).

Address for correspondence:

Dr. K. Šinigoj-Gačnik

Institute for Food Hygiene and Bromatology

Veterinary Faculty, University of Ljubljana

Gerbičeva 60, 1000 Ljubljana, Slovenia
Phone: +38614779 187
Fax: +38614779 174
E-mail: Ksenija.Gacnik@vf.uni-lj.si
http://www.vfu.cz/acta-vet/actavet.htm 
The objective of the present study was to trace the changes of SAL concentration in eggs from laying hens that had been receiving a feed containing $60 \mathrm{mg} \cdot \mathrm{kg}^{-1} \mathrm{SAL}$ for five days. We determined SAL in yolk and albumen from the first day of SAL administration and followed its disappearance after the withdrawal of the feed containing SAL. We also compared the SAL contents in tissues and ovarian yolks in layers sacrificed after 4 days of SAL administration. Food, especially that of animal origin, is usually cooked before consumption; to better understand the behaviour of SAL residues in eggs and to estimate consumer exposure to the residues, we also studied the effect of heat treatment on SAL present in eggs.

\section{Materials and Methods}

Management of birds and experimental design

56-week-old layers, breeding line Hisex, and 35-week-old layers, breeding line Rahmann, were included in the experiment. Hens were allocated in litter floor pens in a controlled environment with a constant access to food and water. There was one group of 10 and two groups of 5 animals, each in a separate pen.

One group of layers with five animals, breeding line Rahmann (group A), received a medicated feed for 4 days, and one group of the breeding line Hisex with ten animals (group B), received a medicated feed for 5 days. SAL was included in the diet as premix, supplied as a $6 \%$ powder Kokcisan ${ }^{\circledR}$, at the concentration of $60 \mathrm{mg} \cdot \mathrm{kg}^{-1}$. On the $5^{\text {th }}$ day three hens from group A were sacrificed and on the $6^{\text {th }}$ day chickens from group B were switched over to the feed free of SAL. One group of 5 layer chickens of the breeding line Hisex (group C) served as a control and received non-medicated feed throughout the experiment.

\section{Collecting samples and analysis}

Eggs from groups B and C were collected every morning from the beginning of the experiment - during treatment and for 10 days after withdrawal - and stored at $+4{ }^{\circ} \mathrm{C}$. On each day the presence of SAL in eggs was determined in five eggs. On the day of analysis, each egg was broken, albumen was separated from yolk and each was analysed separately.

From the three layer chicken from group A sacrificed on day 5 of the experiment, thigh and breast muscle, liver, abdominal fat and ovarian yolks were removed. Tissues from each bird were homogenised, packed in separate bags and stored frozen at below $-18^{\circ} \mathrm{C}$ until the day of analysis. Ovarian yolks were weighed and stored frozen. The control tissues were obtained and prepared in the same way from one randomly selected bird from group C.

For the determination of SAL in egg yolk and albumen we used the method described by Šinigoj-Gačnik (2001). Extraction was achieved with acetonitrile, followed by partitioning between saturated salt and carbon tetrachloride, the organic layer was then further purified by solid phase extraction (SPE) on silica columns. Determination was done with high-performance thin-layer chromatography (HPTLC) with chemical detection using p-anisaldehyde as a derivative reagent. The intensity of coloured spots was measured by densitometry at $510 \mathrm{~nm}$. The recoveries with standard deviation $( \pm \mathrm{SD}$ ) were $85.1 \% \pm 17.4 \%$ and $70.3 \% \pm 10.4 \%$ for egg yolk and albumen, with the detection limit being $10 \mu \mathrm{g} \cdot \mathrm{kg}^{-1}$ and $7.5 \mu \mathrm{g} \cdot \mathrm{kg}^{-1}$, respectively. The calibration curves in the matrix showed good correlation with correlation coefficients 0.9973 and 0.9982 for egg yolk and albumen, respectively. HPTLC with bioautographic detection (Dimenna et al. 1986a) was also performed simultaneously with a detection limit of $7.5 \mu \mathrm{g} \cdot \mathrm{kg}^{-1}$.

For the determination of SAL in muscle and liver tissue the procedure described by Dimenna et al. (1986a) was chosen with some minor modifications as there was no need for purification of the extracts with carbon tetrachloride. SAL was extracted from the muscle and liver tissue by isooctane and SPE followed on silica column. Extraction of SAL from the fat was carried out with a methanol-water mixture, followed by liquid-liquid purification with n-hexane and carbon tetrachloride (Dimenna et al. 1986b). A final cleaning by SPE followed. Thin-layer chromatography (TLC) by bioautographic identification with the test organism B. subtilis (Dimenna et al. 1986a) was used for identification and quantification in order to achieve low detection limits. For muscle and liver tissues ethyl acetate-water $(97+3)$ was used as the mobile-phase, while for the fat, chloroform-methanolammonium hydroxide $(95+5+0.5)$ was preferred. Quantitative evaluation was done by measuring the size of inhibitory zones of $B$. subtilis growth. The recoveries of the methods with standard deviation $( \pm$ SD) were $72.9 \%$ $\pm 8.6 \%, 49.9 \% \pm 9.2 \%$ and $75.3 \% \pm 12.4 \%$ for muscle tissue, liver and fat, respectively. The limits of detection were $7.5 \mu \mathrm{g} \cdot \mathrm{kg}^{-1}, 10 \mu \mathrm{g} \cdot \mathrm{kg}^{-1}$ and $20 \mu \mathrm{g} \cdot \mathrm{kg}^{-1}$ for the muscle tissue, liver and fat, respectively. The calibration curves in the matrix showed a good correlation using a logarithmical relationship, $\mathrm{Y}=\mathrm{m} \ln \mathrm{X}+\mathrm{b}$, where $\mathrm{Y}$ was the area of inhibitory zones of $B$. subtilis growth and $\mathrm{X}$ was the concentration of SAL in the matrix. The correlation coefficients were $0.9928,0.9924$ and 0.9923 for the muscle tissue, liver and fat, respectively.

All quantitative results were achieved using the method of matrix match calibration curve.

Cooking experiment of eggs

Three eggs with incurred SAL were cooked for $5 \mathrm{~min}$. No fat or water was added. Each incurred egg was broken and melange was made. From each egg, half of the prepared melange was analysed in order to determine 
the SAL content without cooking and the other half (ca $20 \mathrm{~g}$ ) was exposed to heat treatment when the egg melange was fried. During frying the melange was stirred all the time and the temperature was monitored with a contact thermometer NiCr-Ni typK, reaching $80^{\circ} \mathrm{C}$ in $2 \mathrm{~min}$ and remaining between 80 to $90{ }^{\circ} \mathrm{C}$ for 3 min. Fried melange was cooled and analyses of the SAL content followed. The same procedure was performed with blank eggs with a standard addition of SAL.

\section{Results and Discussion}

The results of the studies on SAL concentration in eggs after administration of a medicated feed containing $60 \mathrm{mg} \cdot \mathrm{kg}^{-1} \mathrm{SAL}$ to laying hens are summarized in Table 1 and presented in Fig. 1. In egg yolks SAL was first found on the second day of exposure to $\mathrm{SAL}$ in feed. Its concentration grew slowly and reached the maximum value $\left(849 \mu \mathrm{g} \cdot \mathrm{kg}^{-1}\right)$ on the third day after withdrawal. Afterwards, the concentration slowly diminished until some egg yolks became SAL-free on the eighth day after withdrawal. However, some egg yolks still contained minute amounts of SAL (up to $11 \mu \mathrm{g} \cdot \mathrm{kg}^{-1}$ ) until the tenth day after withdrawal. In contrast, the concentrations of SAL in albumen were extremely low ( $5-20 \mu \mathrm{g} \cdot \mathrm{kg}^{-1}$ ), and SAL was present only on the days of receiving the feed that contained it and two days after withdrawal. As can be seen from Table 1, the contents of SAL in egg yolks varied greatly between eggs laid by different animals on the same day. For example, in five analysed eggs laid on the $6^{\text {th }}$ day after withdrawal, the concentrations of SAL in yolk were $13,51,80,152$ and $161 \mu \mathrm{g} \cdot \mathrm{kg}^{-1}$. These findings can be explained by the physiology of egg production. Medicating laying hens leads to accumulation of drugs in egg yolks present in the oviduct during the phase of fast follicular growth and thus high drug concentrations are still to be expected in eggs 7 to 11 days after withdrawal. The drug residues in albumen rapidly diminish since the oviduct only contains water soluble proteins sufficient for the production of two eggs.

Table 1. Concentrations of salinomycin (in $\mu \mathrm{g} \cdot \mathrm{kg}^{-1}$ ) in egg yolk and albumen during the five-day feeding trial of laying hens with medicated feed $\left(60 \mathrm{mg} \cdot \mathrm{kg}^{-1}\right)$ and 10 days post withdrawal

\begin{tabular}{|l|c|c|c|c|c|c|c|c|}
\hline \multirow{2}{*}{$\begin{array}{c}\text { Day of } \\
\text { experiment }\end{array}$} & \multicolumn{4}{|c|}{ Egg yolk } & \multicolumn{4}{c|}{ Albumen } \\
\cline { 2 - 9 } & $\mathrm{N}$ & Min & Max & Average & $\mathrm{N}$ & Min & Max & Average \\
\hline $1^{*}$ & 5 & n.d. & n.d. & n.d. & 5 & n.d. & n.d. & n.d. \\
\hline $2^{*}$ & 5 & n.d. & 80 & 34 & 5 & n.d. & 5 & $<5$ \\
\hline $4^{*}$ & 5 & 10 & 173 & 72 & 5 & n.d. & 20 & 8 \\
\hline $5^{*}$ & 5 & 105 & 258 & 199 & 5 & n.d. & 18 & 12 \\
\hline $6(1)$ & 5 & 175 & 457 & 314 & 5 & 10 & 21 & 15 \\
\hline $7(2)$ & 5 & 310 & 497 & 418 & 3 & n.d. & 13 & 8 \\
\hline $8(3)$ & 5 & 177 & 473 & 359 & 5 & n.d. & 8 & $<5$ \\
\hline $9(4)$ & 5 & 279 & 849 & 480 & 5 & n.d. & n.d. & n.d. \\
\hline $10(5)$ & 5 & 112 & 426 & 272 & 5 & n.d. & n.d. & n.d. \\
\hline $11(6)$ & 5 & 42 & 244 & 134 & 5 & & & n.d. \\
\hline $12(7)$ & 5 & 13 & 161 & 91 & 5 & & & n.d. \\
\hline $13(8)$ & 5 & $<7.5$ & 112 & 50 & 5 & & & n.d. \\
\hline $14(9)$ & 5 & n.d. & 30 & 12 & 5 & & & n.d. \\
\hline $15(10)$ & 5 & n.d. & 9 & $<7.5$ & 5 & & & n.d. \\
\hline
\end{tabular}

* days of feeding with salinomycin n.d. not detected

Our results are comparable to the results published by Aerts (1990) and Akhtar et al. (1996), leading to the conclusion that SAL accumulates in egg yolks progressively, depending on the time of medication and the concentration of SAL in the feed. In our study we also followed the changes of SAL contents in the egg yolk and albumen from the 


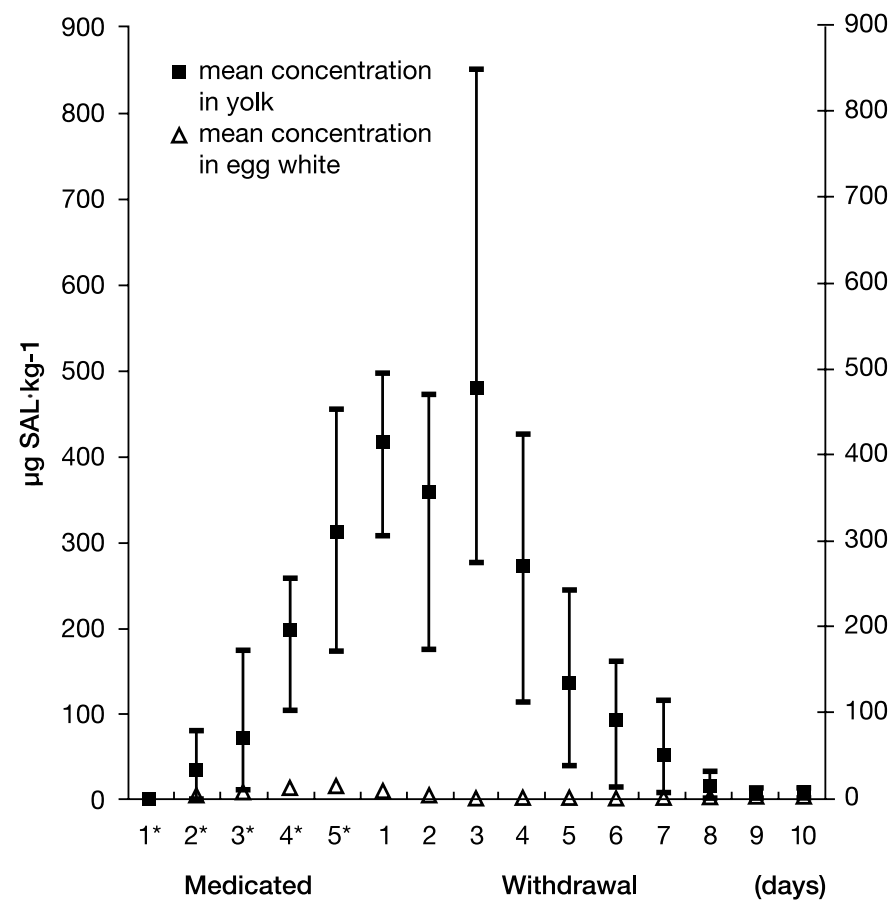

Fig. 1. Concentration of salinomycin (in $\mu \mathrm{g} \cdot \mathrm{kg}^{-1}$ ) in egg yolk and albumen of eggs laid by hens receiving feed containing salinomycin $\left(60 \mathrm{mg} \cdot \mathrm{kg}^{-1}\right)$ for 5 days

beginning of medication and observed its disappearance after withdrawal. The maximum average amounts of SAL in egg yolk were found in eggs from the first to the third day after withdrawal of the medicated feed. With the exception of one egg yolk sample from day 3 after withdrawal which contained $849 \mu \mathrm{g} \cdot \mathrm{kg}^{-1} \mathrm{SAL}$, almost the same maximum amounts were found from the fifth day of medication until the fourth day after withdrawal and ranged between 400 and $500 \mu \mathrm{g} \cdot \mathrm{kg}^{-1}$. The level of SAL in yolk rapidly diminished between the fifth and eighth day after withdrawal, but the rate of disappearance became slower on the ninth and tenth day after withdrawal.

The contents of SAL residues in tissues and ovarian yolks of hens fed for four days with medicated feed are presented in Table 2 and Table 3. No residues of SAL were detected in breast and thigh muscle. In the liver, SAL was present at concentrations $\leq 10 \mu \mathrm{g}^{\mathrm{kg}} \mathrm{kg}^{-1}$, and the concentrations in the abdominal fat ranged from 62 to $237 \mu \mathrm{g} \cdot \mathrm{kg}^{-1}$. With the exception of abdominal fat, residue levels of SAL in tissues were similar to those found in 37-day fed broilers (Korsrud et al. 1996; Šinigoj-Gačnik et al. 1997). The amounts of SAL in the abdominal fat of hens on the day of withdrawal ranged from 63 to $237 \mu \mathrm{g} \cdot \mathrm{kg}^{-1}$ as shown in Table 2, and in broilers the average level was $95 \pm 19 \mu \mathrm{g} \cdot \mathrm{kg}^{-1}$ as reported by Korsrud et al. (1996), and from 31 to $152 \mu \mathrm{g} \cdot \mathrm{kg}^{-1}$ as reported by Šinigoj-Gačnik et al. (1997). This difference can be attributed to different fat compositions in hens and broilers. From these results we can conclude that the time of feeding SAL has no influence on the SAL contents in tissues other than eggs. Contents of SAL found in ovarian yolks of one hen confirmed the accumulation of SAL in ovarian yolk (Table 3 ). The highest quantity was found in the heaviest ovarian yolk. The findings confirm the theory of drug accumulation in the follicles during egg development. Assuming that one egg is laid every day, we understand why the highest concentrations of SAL in yolk were found only after withdrawal. If hens do not 
Table 2. Contents of salinomycin (in $\mu \mathrm{g} \cdot \mathrm{kg}^{-1}$ ) in tissues of hens receiving feed containing salinomycin $\left(60 \mathrm{mg} \cdot \mathrm{kg}^{-1}\right)$ for 4 days and sacrificed on the $5^{\text {th }}$ day

\begin{tabular}{|c|c|c|c|c|}
\hline \multirow{2}{*}{$\begin{array}{c}\text { Laying } \\
\text { hen }\end{array}$} & \multicolumn{3}{|c|}{ Content in tissues $\left(\mu \mathrm{g} \cdot \mathrm{kg}^{-1}\right)$} \\
\cline { 2 - 5 } & Breast muscle & Thigh muscle & Liver & Abdominal fat \\
\hline 1 & n.d. & $<7.5$ & 10 & 237 \\
\hline 2 & n.d. & n.d. & $<10$ & 76 \\
\hline 3 & n.d. & n.d. & $<3$ \\
\hline
\end{tabular}

n.d. not detected

Table 3. Contents of salinomycin in ovarian yolks of laying hen, receiving feed containing salinomycin $\left(60 \mathrm{mg} \cdot \mathrm{kg}^{-1}\right)$ for 4 days and sacrificed on the $5^{\text {th }}$ day

\begin{tabular}{|c|c|c|c|}
\hline Ovarian yolk & $\begin{array}{c}\text { Mass } \\
(\mathrm{g})\end{array}$ & $\begin{array}{c}\text { Content of } \\
\text { salinomycin }(\mathrm{ng})\end{array}$ & $\begin{array}{c}\text { Concentration of } \\
\text { salinomycin }\left(\mu \mathrm{g} \cdot \mathrm{kg}^{-1}\right)\end{array}$ \\
\hline 1 & 18.9 & 4498 & 237 \\
\hline 2 & 11.0 & 4400 & 400 \\
\hline 3 & 6.0 & 3318 & 553 \\
\hline 4 & 0.8 & 416 & 520 \\
\hline
\end{tabular}

lay eggs daily, then prolonged high concentrations of SAL in yolks were observed over a 5-day period.

Results from the cooking experiment are presented in Fig. 2 and show that frying eggs for $5 \mathrm{~min}$ had no influence on the content of SAL.

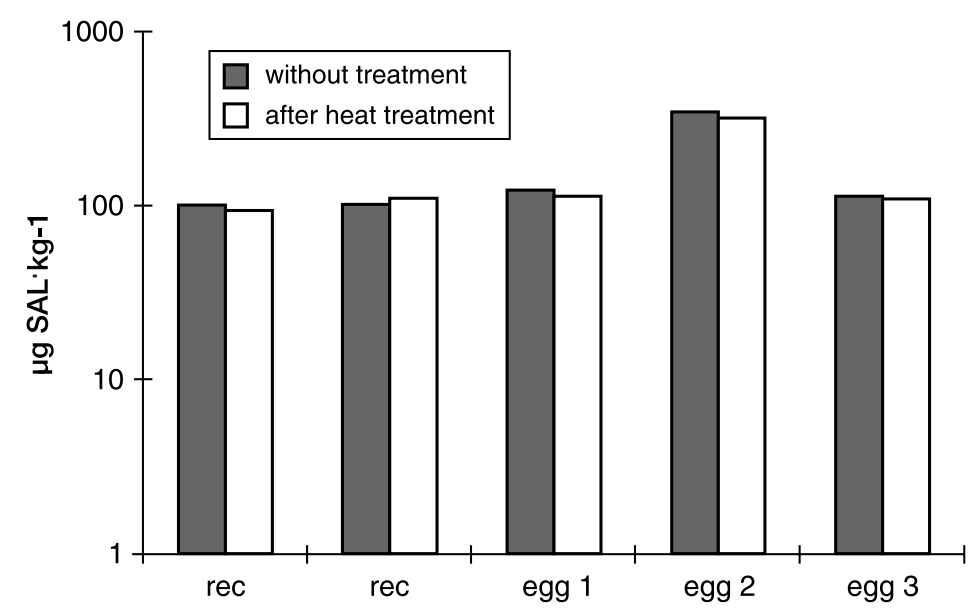

Fig. 2. Concentration of salinomycin (in $\mu \mathrm{g} \cdot \mathrm{kg}^{-1}$ ) before and after 5 min-heat treatment of eggs with standard addition of salinomycin at a concentration of $100 \mu \mathrm{g} \cdot \mathrm{kg}^{-1}$ (rec) and in eggs with incurred salinomycin at a concentration of $123 \mu \mathrm{g} \cdot \mathrm{kg}^{-1}$ (egg 1), $\left.338 \mu \mathrm{g} \cdot \mathrm{kg}^{-1}\right)(\mathrm{egg} 2)$ and $\left.113 \mu \mathrm{g} \cdot \mathrm{kg}^{-1}\right)(\mathrm{egg} \mathrm{3})$

Since SAL possesses cardiovascular properties (Fahim et al. 1986), it could have adverse effects on human health when consumed orally with eggs and other food of animal origin. The exact toxic effects for humans after oral consumption have not yet been clarified, but from a recently published case of accidental human poisoning with SAL in a feed mill (Story and Doube 2004) it is evident that we must not underestimate even the residues of SAL present in eggs, and a careful control of the feed for laying hens and of possible residues of veterinary drugs, especially coccidiostats, in eggs is needed. 


\section{Koncentrace salinomycinu ve vejcích a tkáních nosnic}

Nosnicím bylo pět dní podáváno krmivo obsahující $60 \mathrm{mg} \cdot \mathrm{kg}^{-1}$ salinomycinu sodného. Po ukončení podávání salinomycinu bylo zjišt'ováno množství reziduí v prsní a stehenní svalovině, játrech, abdominálním tuku a žloutkovém vaku. U vajec byla rezidua sledována ve žloutku i v bílku, a to od počátku podávání salinomycinu až do 10. dne po jeho vysazení. Salinomycin byl ve žloutku poprvé zjištěn 2. den od začátku podávání a jeho př́ítomnost setrvávala ještě 8 . den po vysazení. Nejvyšší koncentrace $480 \mathrm{mg} \cdot \mathrm{kg}^{-1}$ byla zjištěna třetí den po vysazení. Koncentrace salinomycinu v bílku byla podstatně nižší, přičemž maximální koncentrace $15 \mathrm{mg} \cdot \mathrm{kg}^{-1}$ byla zaznamenána pátý den po začátku experimentu. Po vysazení byl př́tomen pouze jeden den. U všech nosnic byl ve žloutkovém vaku přítomen salinomycin v koncentracích od 237 do $553 \mathrm{mg} \cdot \mathrm{kg}^{-1}$. Dále byl prítomen v abdominálním tuku (koncentrace od 62 do $237 \mathrm{mg} \cdot \mathrm{kg}^{-1}$ ) a v játrech (koncentrace $\leq 10 \mathrm{mg} \cdot \mathrm{kg}^{-1}$ ), ale nikoli v prsní a stehenní svalovině. Nebyly pozorovány žádné změny v koncentracích salinomycinu po uvaření nebo usmažení vajec.

\section{Acknowledgement}

The research was supported by the Ministry of Education, Science and Sport. We appreciate the support of KRKA d.d. for providing analytical grade sodium salinomycin and the premix Kokcisan ${ }^{\circledR}$. We are also most grateful for the technical help provided by Stanka Zadravec and for the care taken of animals by Martina Pirš.

\section{References}

AERTS MML 1990: Residues of veterinary drugs in edible products, an analytical approach. State Institute for quality control of agricultural products. SSN Press, Nijmegen (The Netherlands), 58 p.

AKHTAR AH, ABOU EL-SOOUD K, SHEHATA A 1996: Concentrations of salinomycin in eggs and tissues of laying chickens fed medicated feed for 14 days followed by withdrawal for 3 days. Food Addit Contam 13: 897-907

ANDREASEN JR, SCHLEIFER JH 1995: Salinomycin toxicosis in male breeder turkeys. Avian Dis 39: 638-642

ATEF M, SHALABY AA, KHAFAGY A, ABO-NORAGE MA 1989: Fetotoxicity of some anticoccidial drugs in chickens. Dtsch Tierarztl Wochenschr 96: 296-298

DIMENNA GP, WALKER BE, TURNBULL LB, WRIGHT GJ 1986a: Thin-layer bioautographic assay for salinomycin in chicken liver. J Agric Food Chem 34: 472-474

DIMENNA GP, GREEGAN JA, TURNBULL LB, WRIGHT GJ 1986b: Determination of sodium salinomycin in chicken skin/fat by high-performance liquid chromatography utilizing column switching and UV detection. J Agric Food Chem 34: 805-810

FAHIM M, DEL VALLE G, PRESSMAN BC 1986: Comparison of the effects of the ionophore salinomycin and adrenalin on the haemodynamics and work efficiency of the dog heart. Cardiovasc Res 20: 145-152

FRANZ J, VERHALEN KH, WACKER R 1992: Salinomycin-Vergiftung in einem Putenmastbestand. Prakt Tierarzt 73: 440-444

HOOP RK 1998: Salinomycin toxicity in layer breeders. Vet Rec 142: 550

JONES JE, SOLIS J, HUGHES BL, CASTALDO DJ, TOLER JE 1990: Reproduction responses of broilerbreeders to anticoccidial agents. Poult Sci 69: 27-36

KAN CA, GEND HW, AERTS MML 1990: The carry-over of low levels of coccidiostats from layers feed to eggs. In: Proceedings of the EuroResidue conference. Noordwijkerhout, May 1990. HAAGSMA N, RUITER A, CZEDIK-EYSENBERG PB (Eds.), Faculty of Veterinary Medicine, Utrecht, pp. 231-234

KENNEDY DG, BLANCHFLOWER WJ, HUGHES PJ, McCAUGHEY WJ 1996: Polyether ionophore residues in eggs in Northern Ireland. In: Proceedings of the EuroResidue III conference. Velthoven, May 1996. HAAGSMA N, RUITER A (Eds.), Faculty of Veterinary Medicine, Utrecht, pp. 601-605

KORSRUD GO, SALISBURY CDC, MARTZ VK, MACNEIL JD, ROYAN G 1996: Depletion of salinomycin residues in tissues of broiler chickens fed rations containing Sacox. In: Proceedings of the EuroResidue III conference. Velthoven, May 1996. HAAGSMA N, RUITER A (Eds.), Faculty of Veterinary Medicine, Utrecht, pp. 625-629

MILLER DJ, O’CONNOR JJ, ROBERTS NL 1986: Tiamulin/salinomycin interactions in pigs. Vet Rec 118: $73-75$

NICPON J, CZERW P, HARPS O, DEEGEN E 1997: Salinomycin poisoning in a Polish stud horse. Tierartzl Prax Ausg G Grosstiere Nutztiere 25: 438-441

ROLLINSON J, TAYLOR FG, CHESNEY J 1987: Salinomycin poisoning in horses. Vet Rec 121: 126-128

STUART JC 1983: Salinomycin poisoning in turkeys. Vet Rec 113: 597 
STORY P, DOUBE A 2004: A case of human poisoning by salinomycin, an agricultural antibiotic. N Z Med J 117: U799

ŠINIGOJ-GAČNIK K 2001: Analysis of polyether antibiotics (salinomycin, monensin, lasalocid) in eggs. Slov Vet Res 38: 141-150

S̆INIGOJ-GAČNIK K, MALENŠEK A, ARH J 1997: Depletion of salinomycin residues in tissues of broiler chickens. In: CESTRNIK V, POGAČNIK A (Eds.): Proceedings of the $2^{\text {nd }}$ Slovenian Veterinary Congress, November 1997. Slovenian Veterinary Association, Ljubljana, pp. 451-454

VAN ASSEN EJ 2006: A case of salinomycin intoxication in turkeys. Can Vet J 47: 256-258

WENDT M, BUSING S, BOLLWAHN W 1997: Toxicity of the combination of salinomycin and tiamulin in swine. Dtsch Tierarztl Wochenschr 104: 405-410 
